\title{
Bottling, Labeling, and Selling Honey in Florida ${ }^{1}$
}

\author{
Amy Vu, Jennifer Hagen, Nancy Gentry, James D. Ellis, and Mary Bammer ${ }^{2}$
}

\section{Intended Audience and Purpose}

The intended audience is for Florida beekeepers of all operation sizes from small scale to commercial. There are 5,000 registered beekeepers in the state, managing almost 700,000 colonies. The Florida Department of Agriculture and Consumer Services have updated their rules and regulations related to honey production and what falls under the 'Cottage Food Law'. This document provides beekeepers with Florida's updates, so they are able to sell honey legally under this law.

Honey producers in Florida have two main avenues for selling their hive products. Commercial operations must be permitted by the Florida Department of Agriculture and Consumer Services Division of Food Safety and must bottle honey in an inspected food facility or establishment. However, small-scale honey producers are exempt from needing a license or permit under Florida's cottage food law by bottling and storing honey in a home kitchen.

A Cottage Food Operation is a natural person or a business entity that produces or packages cottage food products at the residence of a natural person or at the home of a natural person who has an ownership interest in the entity and sells such products in accordance with Section. 500.80, Florida Statutes.

\section{Honey Processors Covered by the Cottage Food Exemption}

Section 500.80, Florida Statutes, and the United States Code of Federal Regulations Title 21, Part 101 (https://www.ecfr. gov/current/title-21) allows individuals to manufacture, sell, and store certain types of "cottage foods" (including honey) in an unlicensed kitchen (primary home kitchen). "Cottage food operations," do not require a food permit from the Florida Department of Agriculture and Consumer Services (FDACS) and are not inspected by any state government entity.

\section{Beekeepers qualify for this exemption provided they:}

- Do not exceed \$250,000 in annual gross sales;

- Upon request, provide the Florida Department of Agriculture and Consumer Services with written documentation to verify their operations' annual gross sales;

- Store all cottage food honey on the premises of the cottage food operation;

- Do not sell, offer for sale, or deliver cottage food products for consignment or "wholesale;"

- Properly label their cottage food products;

- Comply with any state or federal tax law; and

- Comply with all applicable county and municipal laws and ordinances regulating traffic, parking, noise, signage, and hours of home retail operations.

1. This document is ENY-159, one of a series of the Entomology and Nematology Department, UF/IFAS Extension. Original publication date January 2012. Revised February 2022. Visit the EDIS website at https://edis.ifas.ufl.edu for the currently supported version of this publication.

2. Nancy Gentry, beekeeper; James D. Ellis, professor, Entomology and Nematology Department; Mary Bammer, Extension coordinator; Amy Vu, Extension coordinator; and Jennifer Hagen, family and consumer sciences agent I, UF/IFAS Extension Lee County; UF/IFAS Extension, Gainesville, FL 32611

The Institute of Food and Agricultural Sciences (IFAS) is an Equal Opportunity Institution authorized to provide research, educational information and other services

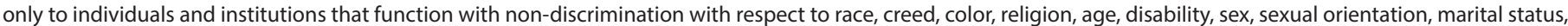

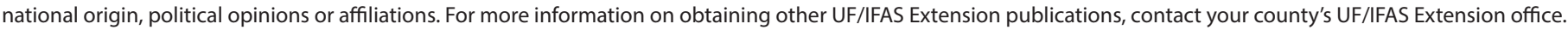
U.S. Department of Agriculture, UF/IFAS Extension Service, University of Florida, IFAS, Florida A \& M University Cooperative Extension Program, and Boards of County Commissioners Cooperating. Andra Johnson, dean for UF/IFAS Extension. 


\section{Activities now Permitted under the "Home Sweet Home Act"}

Beekeepers may continue to sell honey directly to the consumer from the home, a roadside stand, a farmers' market, or a flea market. In addition, honey processors may now advertise for sale, offer, and accept payment for cottage food products over the internet or by mail order. Products may be sold and delivered directly to the consumer, to a specific event venue, or shipped interstate by United States Postal Service or commercial mail delivery service.

\section{Requirements for Cottage Food Labels}

Cottage food products must be labeled with the requirements as outlined in Section 500.80 (3) http://www. leg.state.fl.us/statutes/index.cfm?App_mode=Display_ Statute\&Search_String=\&URL=0500-0599/0500/Sections/0500.80.html

The honey must be pre-packaged (bottled or cut comb in containers) with a label affixed that contains the following information (printed in English):

- The name and address of the cottage food operation. The beekeeper must list his/her name, or business entity that produces or packages cottage food products at the residence on the label. No fictitious names are permitted under the cottage food operation legislation.

- The complete street address of the cottage food operation including zip code (post office box address does not qualify).

- The name of the product. The single word "honey" is acceptable. Honey as defined by the Florida Standard of Identity for Honey (Rule: 5K-4.027) means "the natural food product resulting from the harvest of nectar by honey bees and the natural activities of the honey bees in processing nectar. It consists essentially of different sugars, predominately fructose and glucose, and other substances such as organic acids, enzymes and solid particles derived from honey collection. The color of honey can vary from nearly colorless to dark brown. The consistency can be fluid, viscous, or partially to completely crystallized. The flavor and aroma vary but are derived from the plant's origin" (https://www.flrules.org/ gateway/ruleno.asp?id=5K-4.027).

- The ingredients of the cottage food product, in descending order of predominance by weight. If honey contains any flavoring, spice, or other added ingredient, those additives must also appear on the label. For example, "lime essence honey." See Florida Department of Agriculture and Consumer Services Rule 5K-4.027 (4) Standard Identity for Honey (https://www.flrules.org/ gateway/ruleno.asp?id=5K-4.027).

- The net weight or net volume of the cottage food product. The product's content should be expressed in net weight or net volume. The statement must be displayed in the bottom $30 \%$ of the label. The words "net weight" may be abbreviated to "Net.Wt.".

- Allergen information as specified by federal labeling requirements. The Food Allergen Labeling and Consumer Protection Act requires food labels to identify in plain English if the product contains any of the eight major food allergens-milk, eggs, fish, crustacean shellfish, peanuts, tree nuts, wheat, and soybeans. The Act does not include honey, and honey is not listed as an allergen. However, honey has been associated with infant botulism and, is considered a dietary risk for infants less than one year of age. It is recommended beekeepers display on their labels, "Do not feed to infants less than one year old." See the following document for more information: http://edis.ifas.ufl.edu/aa142.

- The following statement must be in at least 10-point type in a color that provides a clear contrast to the background of the label: "Made in a cottage food operation that is not subject to Florida's food safety regulations."

The following is an example of the minimum information required on a cottage food product label for honey (except for the infant statement which is recommended but not mandatory):

MADE IN A COTTAGE FOOD OPERATION THAT

IS NOT SUBJECT TO FLORIDA'S FOOD SAFETY REGULATIONS (10pt type)

HONEY

John Doe

445 W. $39^{\text {th }}$ Av

Tallahassee, FL 32399

Net Wt. $160 z$

Do not feed to infants less than one year old

Figure 1. Example of the minimum information required on a cottage food product label for honey.

Credits: undefined 


\section{Additional Cottage Food Labeling Information}

Words to avoid: Avoid any nutritional claims or health related statements on the label (for example "healthy," "packed with energy," "low in fat," "good for allergies") because such statements would also require the cottage food to display a nutritional content label. There is no official standard for "raw" honey; however, it generally means that the honey has not been filtered or heated. When customers ask for raw honey, they want honey that has only been strained, so avoid labeling or selling honey as "raw" unless it will meet the customer's expectations. Never use the words "certified," "registered," or "inspected" on your honey label unless your product has been certified, registered, or inspected by an authorized entity. The word "organic" is not just an adjective, nor is it synonymous with "natural." If you wish to produce or handle agricultural products that can be sold, labeled, or represented as "100 percent organic," "organic," "made with organic ingredients," or "USDA Organic," you must be certified by an accredited certifying agent. More information on how to become certified can be found on the National Organic Program website (https://www.ams.usda.gov/about-ams/programs-offices/ national-organic-program).

Optional words you may use: Words preceding the word "honey," such as "pure," "natural," or "all natural" are acceptable and reinforce the quality and purity of the product. Honey may also be designated according to floral or plant source (for instance, "orange blossom honey") if it comes predominately from that source and has the scientific properties corresponding with that origin. Beekeepers should avoid preceding the floral source with the word "pure" because bees do not exclusively use one floral source.

\section{Additional Cottage Food}

\section{Regulations}

Gross sales of cottage foods are for all foods produced and sold, not just honey. For example, if you sell honey and jam under the cottage food exemption, the combined gross sales of these products cannot exceed $\$ 250,000$ annually.

A local law, ordinance, or regulation may not prohibit a cottage food operation or regulate the preparation, processing, storage, and sale of cottage food products by a cottage food operation or from a person's residence. A cottage food operation must comply with all applicable county and municipal laws and ordinances regulating traffic, parking, noise, signage, and hours of the home-based retail operation. Check with your county, local municipality, and farmers' markets before selling to the public.

The Florida Department of Agriculture and Consumer Services may investigate any complaint that alleges that a cottage food operation has violated an applicable provision of this chapter or rule adopted under this chapter (http:// www.leg.state.fl.us/statutes/index.cfm?App_mode=Display_ Statute\&URL=0500-0599/0500/Sections/0500.80.html)

Only upon receipt of a complaint may an officer or employee of the Florida Department of Agriculture and Consumer Services inspect the premises of a cottage food operation to determine compliance with applicable state law and departmental rules. You may advertise and accept orders and payments online or by mail order. You may deliver the cottage food product directly to the consumer or to a specific event venue, or ship the product interstate by United States Postal Service or commercial mail delivery service.

\section{Honey Processing Outside of the Cottage Food Industry}

Honey processors whose gross sales exceed \$250,000 annually and/or who sell their honey by consignment or wholesale are not exempt under cottage food operations (Section 500.80 Florida Statutes).

These honey processors must be properly permitted by the Florida Department of Agriculture and Consumer Services and must bottle honey in a permitted food establishment.

Beekeepers owning a food establishment must apply for a Food Establishment Permit (see Retail Food Establishment Permitting Requirements: https://www.fdacs.gov/ Business-Services/Food/Food-Establishments/RetailFood-Establishment-Permit). The minimum construction standards for food establishments in Florida can be found here: https://www.fdacs.gov/content/download/64038/ file/FOOD-ESTABLISHMENT-MINIMUMCONSTRUCTION-STANDARDS.PDF. Beekeepers not owning a food establishment but wanting to lease, rent, or use a food establishment for bottling must submit to FDACS a commissary letter of agreement certifying that the owner of the commissary gives permission to bottle on the premises. The premises will be inspected annually by the Florida Department of Agriculture and Consumer Services. Honey must be stored on the commissary premises and not at private residences. Beekeepers selling their honey at a location other than the commissary are required to hold a Mobile Food Vendor license. 
Honey processors in this category are prohibited from displaying on their label, "Made in a cottage food operation that is not subject to Florida's food safety regulations."

Net quantity of contents on label must be expressed in both metric (grams, kilograms, milliliters, liters) and US Customary System (ounces, pounds, fluid ounces).

The following is an example of minimum requirements for labeling for honey processors selling wholesale or retail, and/or whose grosses exceed $\$ 250,000$ annually (except for the infant statement, which is recommended but not mandatory):

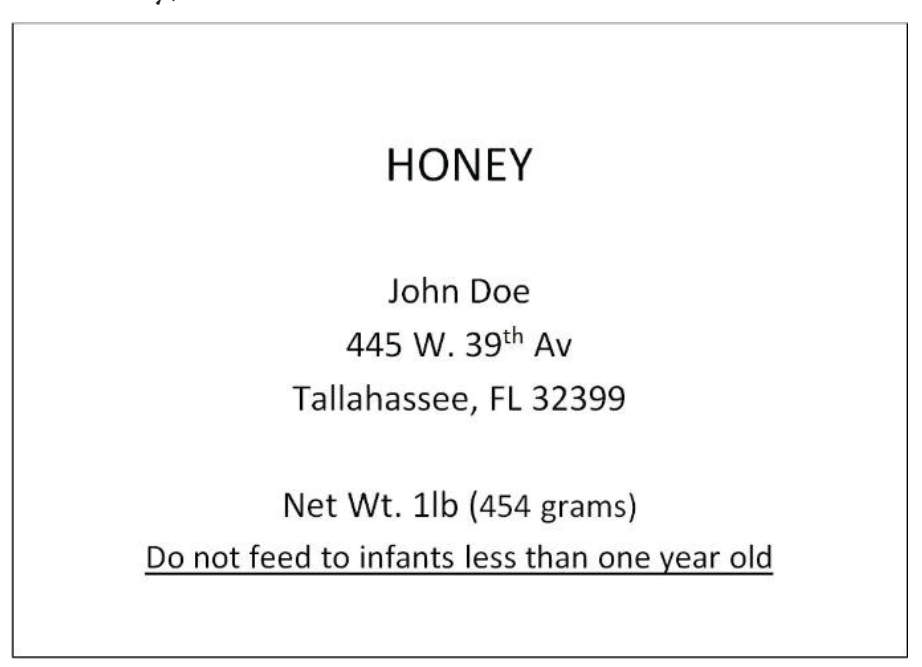

Figure 2. Example of minimum requirements for labeling for honey processors selling wholesale, retail, mail order or internet sales (except for the infant statement, which is recommended but not mandatory). Credits: undefined

\section{Nutritional Labeling}

Nutritional labeling is mandatory for most foods. Honey processors who must include a nutritional food label on their honey should refer to the United States Code (USC) of Federal Regulations, Title 21, Part 101. (https://www. accessdata.fda.gov/scripts/cdrh/cfdocs/cfcfr/CFRSearch. cfm?CFRPart=101). See also National Honey Board (https://www.honey.com/).

Products sold by companies qualifying for small business exemptions are one exception to the nutritional labeling requirement. Small-business exemptions are available for products sold in small volume (fewer than 100,000 units per year) and by small companies (fewer than 100 employees). To apply for the exemption, contact the Food and Drug Administration's Office of Food Labeling at 301-436-2371 or visit their website for the proper forms. If you are not an importer, have fewer than 10 full-time employees, and sell fewer than 10,000 total units, you do not have to file a notice of exemption. (https://www.fda.gov/ regulatory-information/search-fda-guidance-documents/ small-business-nutrition-labeling-exemption-guidance).

If you use certain descriptors such as "healthy" on your label, there must be a nutritional label on the product, even if the product is otherwise exempt. Whenever a nutrient content claim is made on a label, the claim must be accompanied by a "referral statement" directing the consumer to the panel on which the nutritional fact information is located (i.e., "See side panel for nutritional information").
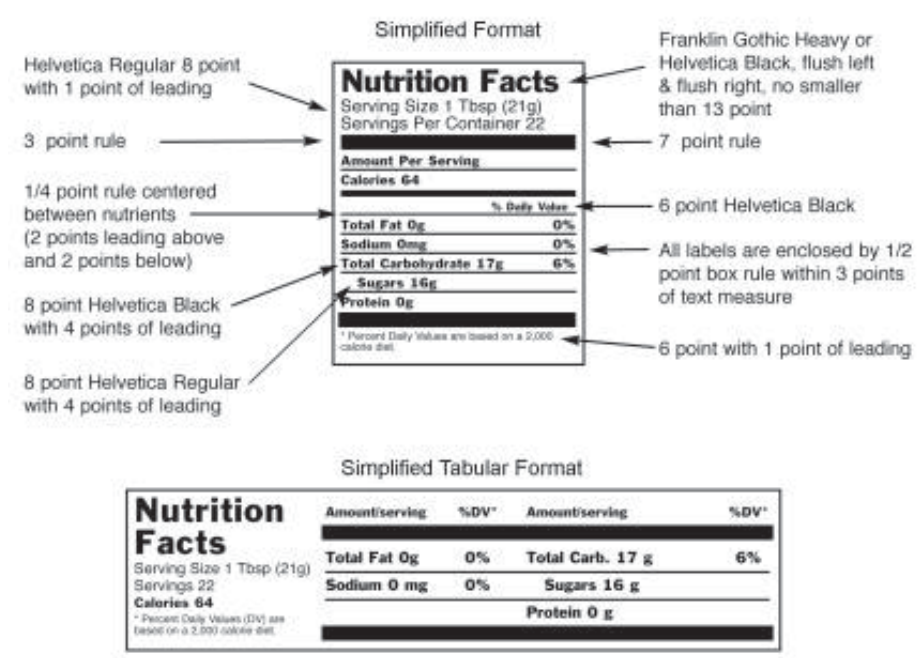

Simplified Linear Format

Nutrition Facts Serv size: 1 Tosp (21g). Servings: 22, Amount Per Serving: Calories 64. Total Fat $0 \mathrm{~g}(0 \%$ DV). Sodium $0 \mathrm{mg}(0 \%$ DV). Total carb. $17 \mathrm{~g}(6 \%$ DV), Sugars $16 \mathrm{~g}$. Protein 0 g. Percent Daily Values (DV) are based on a 2,000 calorie diet.

Figure 3. Sample nutritional label for a one-pound jar of honey. Credits: National Honey Board (https://www.honey.com)

\section{Common Labeling Mistakes}

The most common mistakes made in honey labeling (including cottage food operations and honey processing) are:

- placing the net contents in the upper part of the label-it must be in the lower $30 \%$;

- using an improper "Net Weight" statement;

- omitting a portion of the address, particularly the zip code;

- claiming a "pure" flora source; and

- improperly identifying a blended honey with a single floral source. 


\section{Additional Resources}

For further information regarding bottling, labeling, and selling of honey in Florida, contact the Florida Department of Agriculture and Consumer Services, (850) 245-5520 or read the FDACS guidance on Cottage Food Operations here: https://www.fdacs.gov/content/download/70108/ file/Cottage-Food-Brochure.pdf . For further information on cottage foods legislation please visit FDACS, Division of Food Safety website (https://www.fdacs.gov/ Divisions-Offices/Food-Safety). 